\title{
ANALISIS PENGARUH KEPEMIMPINAN, LINGKUNGAN KERJA DAN KEMAMPUAN KERJA TERHADAP PRESTASI KERJA PEGAWAI BADAN KESATUAN BANGSA DAN POLITIK KABUPATEN KERINCI
}

\author{
Ferry Siswadhi \\ Sekolah Tinggi Ilmu Ekonomi Sakti Alam Kerinci \\ Email: fsiswadhi@gmail.com
}

\begin{tabular}{l}
\hline \multicolumn{1}{c}{ Artikel info } \\
\hline Artikel history: \\
Diterima: 25 Oktober \\
2020 \\
Diterima dalam bentuk \\
revisi: 06 November 2020 \\
Diterima dalam bentuk \\
revisi: 19 November 2020
\end{tabular}

Keywords: Leadership, Work Environment, Work Ability, Work Achievement
Abstract : This study aims to determine the influence and magnitude of influence: Leadership, Work Environment, and Work Ability Towards Work Performance of Kerinci Nation's Political and National Unity Agency Employees Silmultically and Partially. The population of this study were all civil servants in the Kerinci Regency National Unity and Politics Agency, totaling 30 people. Data is collected by a questionnairethat has been tested for validity and reliability. The data analysis technique used is multiple linear regression. The results of this study indicate that Leadership influences theWork Achievement of Employees of the National Unity Agency and Politics of Kerinci Regency, this is proven by proven $t$ count $>t$ table (2,101> 2,05553). Work Environment influences the Work Achievement of Employees of the National Unity Agency and Politics of Kerinci Regency, this is evidenced by $t$ arithmetic $>t$ table (2.549> 2.05553). Work Ability has a negative effect on the Work Achievement of Employees of the National Unity Board and Politics of Kerinci Regency, this is evidenced by $t$ count $<t$ table (-0.889 <2.05553). Simultaneously there is a significant influence between Leadership, Work Environment, and Work Ability on Work Performance of Kerinci Regency's National Unity and Politics Employees, which can be proven by $F$ arithmetic > F table(3.319> 2.96). The influence of Leadership, Work Environment and Work Ability on the work performance of the Kerinci Regency National Unity and Violence Agency is $27.7 \%$ while the rest $(100 \%-27.7 \%)$ that is $72.3 \%$ is explained by other factors not examined in this study.

Abstrak: Penelitian ini bertujuan untuk mengetahui pengaruh dan besarnya pengaruh: Kepemimpinan, Lingkungan Kerja, Dan Kemampuan Kerja Terhadap secara Silmultan dan Parsial. Populasi dari penelitian ini adalah seluruh PNS pada Badan Kesatuan Bangsa Dan Politik

Kabupaten Kerinci yang berjumlah 30 orang. Data 
Kata Kunci :

Kepemimpinan, Lingkungan Kerja, Kemampuan Kerja, Prestasi Kerja dikumpulkan dengan kuesioner yang telah diuji validitas dan reabelitasnya. Teknik analisis data yang digunakan adalah regresi linear berganda. Hasil Penelitian ini menunjukkan bahwa Kepemimpinan berpengaruh terhadap Prestasi Kerja Pegawai Badan Kesatuan BangsaDan Politik Kabupaten Kerinci, ini dibuktikan dengan dibuktikan $\mathrm{t}$ hitung $>\mathrm{t}$ tabel $(2,101>$ 2,05553). Lingkungan Kerja berpengaruh terhadap Prestasi Kerja Pegawai Badan Kesatuan BangsaDan Politik Kabupaten Kerinci, ini dibuktikan dengan $\mathrm{t}$ hitung > t tabel (2,549> 2,05553). Kemampuan Kerja Kerja berpengaruh negatif terhadap Prestasi Kerja Pegawai Badan Kesatuan BangsaDan Politik Kabupaten Kerinci, ini dibuktikan dengan $t$ hitung $<\mathrm{t}$ tabel ($0,893<2,05553)$. Secara simultan terdapat pengaruh yang signifikan antara Kepemimpinan, Lngkungan Kerjai, Dan Kemampuan Kerja Terhadap yaitu dapat dibuktikan dengan F hitung .> F tabel $(3,319>2,96)$. Pengaruh Kepemimpinan, Lingkungan Kerja dan Kemampuan Kerja terhadap prestasi kerja Badan Kesbangpol Kabupaten Kerinci sebesar 27,7\% sedangkansisanya $(100 \%$ - 27,7\%) yaitu $72,3 \%$ dijelaskan oleh faktor-faktor lain yang tidak diteliti dalam penelitian ini.

Koresponden author: Ferry Siswadhi

Email: fsiswadhi@gmail.com

artikel dengan akses terbuka dibawah lisensi

CC BY SA

\section{Pendahuluan}

Setiap organisasi ingin menghasilkan prestasi yang tinggi dan perspektif, untuk mencapai hal tersebut maka peranan pegawai sangat menentukan. Keadaan tidak puas pegawai dalam bekerja akan mengakibatkan suatu situasi yang tidak menguntungkan baik secara organisasi maupun individual. Puas atau tidak puasnya seorang pegawai akan bisa dilihat dari perilaku dan hasil kerjanya. Masih banyak pegawai yang kurang optimal dalam menunjukkan kepegawaian sebaik-baiknya akibat kurangnya semangat kerja yang tinggi untuk bisa menuntaskan pekerjaannya. Selain waktu kerja rutin yang menjadi tanggung jawab masingmasing pegawai, bisa dikatakan bahwa sebagian pegawai kurang aktif untuk mengikuti kegiatan- kegiatan lain yang di selenggarakan organisasi. Baik yang sifatnya formal maupun informal. Keenganan pegawai melakukan melebihi dari apa yang diharapkan juga menyebabkan dorongan untuk berkompetisi meraih prestasi yang lebih baik dari pegawai lainnya. Keberhasilan suatu organisasi dalam mengejar kausalitas tidak hanya tergantung pada bagaimana organisasi mengembangkan kompetensi anggota organisasinya, namun juga pada bagaimana organisasi menigkatkan komitmen para anggotanya, baik komitmen pada pegawai maupun pada arahan atasan. 
Direktorat Jenderal Kesatuan Bangsa dan Politik Kementerian Dalam Negeri atau disingkat dengan Kesbangpol Kemendagri merupakan salah satu direktorat dari Kementerian Dalam Negeri yang mempunyai tugas menyelenggarakan urusan pemerintahan dalam negeri untuk membantu presiden dalam menyelenggarakan pemerintahan negara. Kesbangpol Kemendagri dipimpin oleh Direktur Jenderal Kesbangpol. Pada tahun 2015 Ditjen Kesbangpol berganti nama menjadi Direktorat Jenderal Politik dan Pemerintahan Umum Direktorat Jenderal Kesatuan Bangsa dan Politik yang dahulu dikenal dengan Direktorat Jenderal Sosial Politik sudah 4 (empat) kali mengalami perubahan nama nomenklatur yaitu dari Direktorat Jenderal Sosial Politik berubah menjadi Direktorat Jenderal Kesatuan Bangsa dan Perlindungan Masyarakat berubah lagi menjadi Direktorat Jenderal Kesatuan Bangsa dan sekarang menjadi Direktorat Jenderal Kesatuan Bangsa dan Politik dengan Peraturan Menteri dalam Negeri Nomor 41 Tahun 2010 tentang Organisasi dan Tata Kerja Kementerian Dalam Negeri

Menurut (Sutrisno et al., 2014) Prestasi kerja adalah hasil kerja yang telah dicapai seseorang daritingkah laku kerjanya dalam melaksanakan aktivitas kerja, Prestasi kerja adalah proses evaluasi atau unjuk kerja pegawai yang dilakukan oleh organisasi, setiap pegawai diharapkan dapat selalu berprestasi dengan baik dalam pekerjaannya. Menurut (Simanjuntak, Payaman, 2011) prestasi kerja akan dipengaruhi oleh tiga faktor yaitu:

1) Kualitas dan Kemampuan Kerja, Kualitas dan kemampuan fisik sangat dipengaruhi oleh tingkat pelatihan, pendidikan, etos kerja, motivasi kerja, sikap mental dan kemampuanfisik karyawan yang bersangkutan.

2) Sarana pendukung, bagi peningkatan prestasi/produktivitas kerja ini dapat dikelompokkan ke dalam dua golongan yaitu Menyangkut Lingkungan Kerja, temasuk teknologi dan pelayanan, sarana dan peralatan yang digunakan, tingkat kesehatan kerja, serta suasana dalam Lingkungan Kerja itu sendiri. Menyangkut kesejahteraan pegawai, yang tercermin dalam sistem pengupahan dan jaminan sosial, serta jaminan bagi kelangsungan kerja pegawai.

3) Supra Sarana, Aktivitas perusahaan tidak bisa terlepas dari pengaruh yang terjadi diluarnya, seperti sumber-sumber alat yang digunakan, prospek pemasaran, lingkungan hidup dan lain-lain.

Sedangkan menurut (Afifi et al., 2015) adapun faktor yang mempengaruhi Prestasi Kerja yaitu Motivasi kerja, Kemampuan Kerja, Gaya Kepemimpinan, dan Disiplin kerja.

\section{a. Prestasi Kerja}

\section{Pengertian Prestasi Kerja}

Menurut (Sutrisno et al., 2014) Prestasi kerja adalah hasil kerja yang telah dicapai seseorang dari tingkah laku kerjanya dalam melaksanakan aktivitas kerja, Prestasi kerja merupkan proses evaluasi atau unjuk kerja pegawai yang dilakukan olehorganisasi, setiap pegawai diharapkan dapat selalu berprestasi dengan baik dalam pekerjaannya. Dalam hal ini tentunya tugas-tugas yang dibebankan kepadanya dapat diselesaikan dengan baik dalam arti disertai kecakapan, disiplin, serta tanggung jawab yang tinggi. Apabila keadaan ini dapat tercipta maka tentunya akan berpengaruh terhadap hasil kerja para pegawai baik kualitas maupun kuantitasnya. 


\section{Indikator Prestasi Kerja}

Indikator prestasi kerja menurut (Sutrisno et al., 2014) sebagai berikut:

1) Hasil Kerja : Tingkat kuantitas maupun kualitas yang telah dihasilkan dan sejauh mana pengawasan dilakukan.

2) Pengetahuan Pekerjaan : Tingkat pengetahuan yang terkait dengan tugas pekerjaan yang akan berpengaruh langsung terhadap kuantitas dan kualitas dari hasil kerja.

3) Inisiatif : Tingkat inisiatif selama melaksanakan tugas pekerjaan khususnya dalam hal penanganan masalah - masalah yang timbul.

4) Kecakapan Mental : Tingkat kemampuan dan kecepatan dalam menerima instruksi kerja dan menyelesaikan dengan cara kerja serta situasi kerja yang ada.

5) Sikap : Tingkat semangat kerja serta sikap positif dalam melaksanakan tugas pekerjaan.

6) Disiplin waktu dan absensi

\section{b. Kepemimpinan}

\section{Pengertian Kepemimpinan}

Menurut (Rivai \& Mulyadi, 2003) kepemimpinan adalah kemampuan seseorang pemimpin untuk mempengaruhi orang lain dengan cara memancing tumbuhnya perasaan yang positif dalam diri orang-orang yang dipimpinnya untuk mencapai tujuan yang diinginkan.

\section{Indikator Kepemimpinan}

(Rivai \& Mulyadi, 2003) mengemukakan bahwa seorang pemimpin dalam mengimplementasikan kepemimpinannya harus mampu secara dewasa melaksanakan kedewasaan terhadap instansi atau organisasinya, kepemimpinan dibagi kedalam lima dimensi dan sembilan indikator, yaitu :

1) Kemampuan untuk membina kerjasama dan hubungan yang baik

a. Membina kerjasama dan hubungan baik dengan bawahan dalam pelaksanaan tugas yang menjadi tanggung jawab masing- masing.

b. Kemampuan seorang pemimpin dalam memotivasi bawahannya.

2) Kemampuan yang efektivitas
a. Mampu menyelesikan tugas diluar kemampuan.
b. Menyelesaikan tugas tepat waktu.
c. Hadir tepat waktu dan tidak terlambat.

3) Kepemimpinan yang partisipatif

a. Pengambilan keputusan secara musyawarah.

b. Dapat menyelesaikan masalah secara tepat.

c. Mampu dalam meniliti masalah yang terjadi pada pekerjaan.

4) Kemampuan dalam mendelegasikan tugas atau waktu

a. Bersedia untuk membawa kepentingan pribadi dan organisasi kepada kepentingan yang lebih luas, yaitu kepentingan organisasi menggunakan waktu sisa untuk keperluan pribadi.

b. Mampu dalam menyelesaikan tugas sesuai dengan target.

5) Kemampuan dalam mendelegasikan tugas atau wewenang

a. Tanggung jawab seorang pemimpin dalam menyelesaikan tugas mana yang harus ditangani sendiri dan mana yang harus ditangani secara kelompok. 
b. Memberikan bimbingan dan pelatihan dalam pengambilan keputusan

\section{c. Lingkungan kerja}

\section{Pengertian Lingkungan Kerja}

Menurut (Nitisemito, 2004), lingkungan kerja adalah suatu keadaan yang terdapat dalam struktur dan proses kegiatan perusahaan yang mencerminkan rasa kepuasan pada para pelaksana atau pegawai yang bersifat menunjang ke arah pencapaian cita-cita yang diinginkan oleh perusahaan secara keseluruhan maupun oleh pelaksana.

\section{Indikator Lingkungan Kerja}

Menurut (Nitisemito, 2004). Beberapa indikator yang digunakan untuk pengukuran lingkungan kerja dalam penelitian ini adalah sebagai berikut :

1) Rekan kerja yang mendukung : Suatu pekerjaan akan dapat dilaksanakan dengan baik apabila ada dukungan yang baik dari rekan kerja dikantor, sebab seorang pegawai berinteraksi dengan sesama rekan kerja sehingga diperlukan adanya dukungan yang baik dan kondusif.

2) Kondisi ruangan kerja : Penyelesaian suatu pekerjaan berkaitan erat dengan kondisi ruangan kerja yang baik, sebab dengan adanya ruangan kerja yang baik akan dapat memberikan kenyamanan dan ketenangan pegawai dalam menyelesaikan tugas.

3) Perlengkapan kerja yang mendukung : Perlengkapan kerja yang cukup dan memadai serta mengikuti perkembangan teknologi modern akan sangat mendukung penyelesaian suatu pekerjaan oleh karyawan. Penggunaaan perlengkapan yang optimal dan modern akan menambah nilai efektifitas pegawai dalam bekerja.

\section{d. Kemampuan Kerja}

\section{Pengertian Kemampuan Kerja}

Kemampuan kerja adalah suatu hal yang harus dimiliki karyawan. Hal ini dikarenakan dalam menyelesaikan pekerjaan yang diberikan perusahaan kepada karyawan, karyawan dapat menyelesaikan pekerjaannya dengan baik dan sesuai dengan jangka waktu yang telah ditetapkan perusahaan. Kemampuan yang dimiliki karyawan biasanya terdapat dua hal yaitu kemampuan mental dan kemampuan fisik (Winardi, 2004).

\section{Indikator Kemampuan Kerja}

Menurut (Winardi, 2004), indikator kemampuan kerja yaitu :

1) Keterampilan (skill) : Keterampilan dan kecakapan karyawan sebagai akumulasi dari bakat dan kepribadian yang dimiliki oleh setiap karyawan. Bentuk dari indikator skill meliputi mampu menyelesaikan tugas tepat pada waktunya, kreatif, inovatif, dan memiliki kemampuan untuk menguasai bidang tertentu sesuai level jabatan.

2) Pengetahuan (knowledge) : Pengetahuan (knowledge) merupakan pengetahuan yang dimiliki sebagai hasil pendidikan, pengalaman, dan pelatihan di bidang kerjanya. Pengalaman kerja (work experience). 


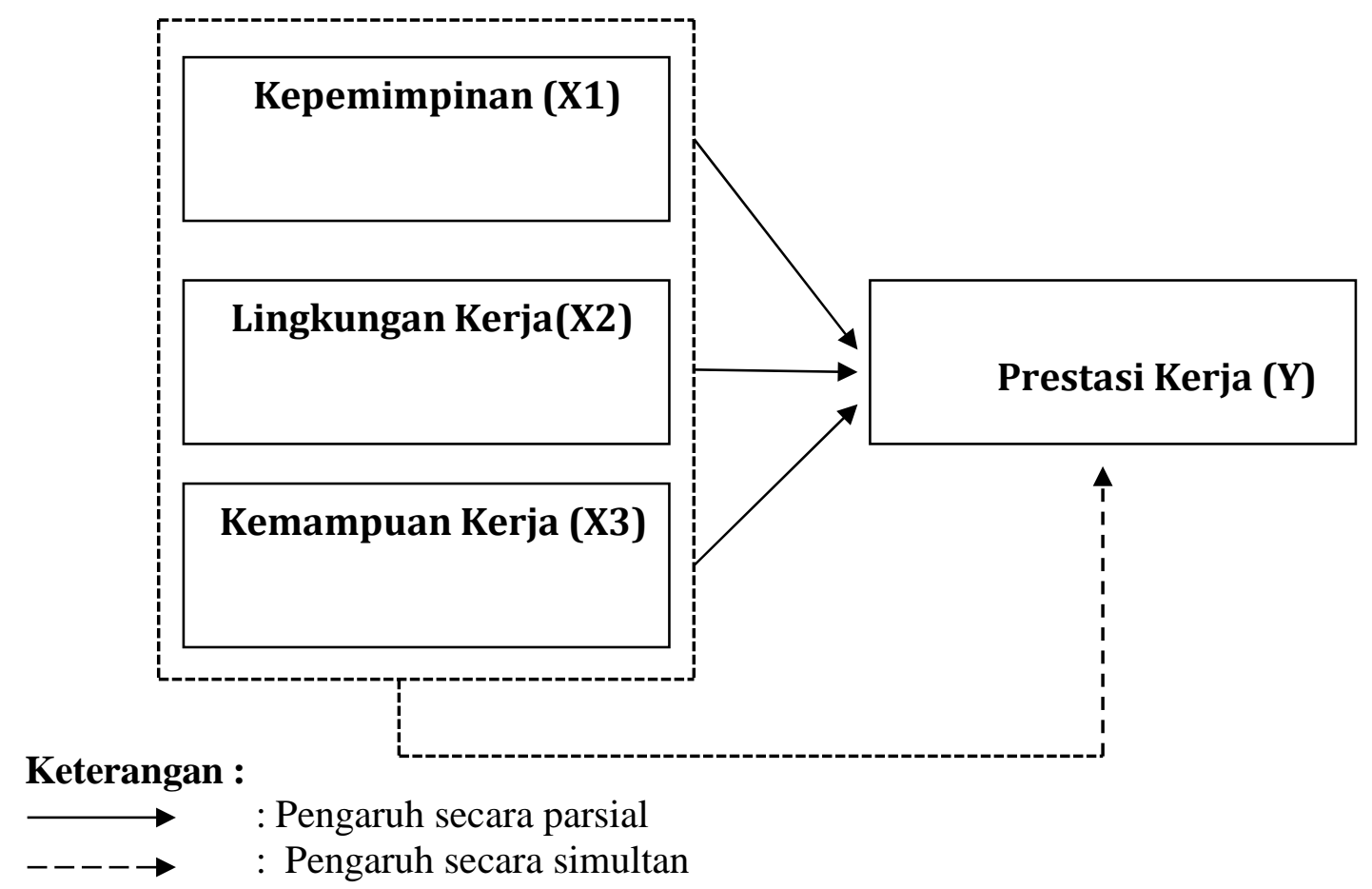

Gambar 1. Kerangka Konseptual

\section{Metode Penelitian}

A. Ruang Lingkup Penelitian

Penelitian ini merupakan penelitian deskriptif kausalitas yang dilakukan untuk menguji hipotesa yang diajukan dengan menggunakan metode penelitian yang telah dirancang sesuai dengan variabel variabel yang akan diteliti agar mendapatkan hasil penelitian yang akurat, adapun variabel nya yaitu Kepemimpinan (X1), Lingkungan Kerja (X2), dan Kemampuan Kerja (X3) serta Prestasi Kerja (Y). Maka diperlukan dukungan data dari objek penelitian, yang penulis jadikan objek dalam penelitian ini adalah Badan Kesatuan Bangsa Dan Politik Kabupaten Kerinci penelitian ini dilakukan selama 30 hari mulai dari 1 Maret sampai 1 April.

B. Populasi dan Sampel

Populasi adalah wilayah generalisasi yang terdiri atas obyek atau subyek yang mempunyai kuantitas dan karakteristik tertentu yang ditetapkan oleh peneliti untuk di pelajari dan kemudian di tarik kesimpulannya (Sugiono, 2004). Populasi dalam penelitian ini adalah PNS di Badan Kesatuan Bangsa Dan Politik Kabupaten Kerinci yang berjumlah 31 orang.

Menurut (Sugiono, 2008) sampel adalah sebagian dari populasi dan karakter yang di miliki oleh populasi tersebut. Sampel dalam penelitian ini di ambil dari jumlah populasi untuk dijadikan sempel atau metode sampel jenuh. Hal ini sesuai dengan pendapat sugiono (2005) yang menyatakan apabila objeknya kurang dari 100 maka populasi tersebut dapat diambil langsung untuk dijadikan sampel. Mengacu pada pendapat diatas maka peneliti hanya mengambil sampel yang berstatus Pegawai Negeri Sipil (PNS) saja dengan jumlah sampel dalam penelitian ini adalah sebanyak 
30 responden (tidak termasuk kepala badan) mengingat salah satu variabel yang diteliti dalam penelitian ini adalah tentang kepemimpinan. Oleh karena itu jumlah sampel yang digunakan hanya 30 sampel.

1. Alat Analisis Data

a. Analisis Deskriptif

Metode deskriptif kualitatif adalah analisis yang menjelaskan dengan kata-kata dari data yang sudah diolah kecuali dihitung dalam persentase tentang data yang diketahui dilakukan dalam pembahasan penelitian ini. Tujuan analisis ini untuk membuat deskripsi, gambaran atau lukisan secara sistematis dan aktual mengenai fakta-fakta yang ada di lapangan dengan teori, konsep-konsep yang ada pada literatur terkait.

b. Metode Deskriptif Kuantitatif

Metode deskriptif kuantitatif merupakan alat untuk menganalisis dengan melakukan perhitungan Kepemimpinan, Lingkungan Kerja dan Kemampuan Kerja terhadap Prestasi Kerja. metode analisa berbentuk angka-angka, dalam hal ini dipakai analisa statistik. Analisa statistik adalah suatu metode guna memperoleh, mengolah dan menyajikan, menganalisa serta menginterprestasikan data yang berwujud angkaangka.

c. Regresi Linear Berganda

Persamaan regresi linear berganda menurut (Sugiyono, 2008) adalah sebagai berikut :

$\mathrm{Y}=\mathrm{a}+\mathrm{b} 1 \mathrm{X} 1+\mathrm{b} 2 \mathrm{X} 2+\mathrm{e}$

Dimana:

$$
\begin{aligned}
& \mathrm{Y}=\text { Prestasi Kerja } \\
& \mathrm{a} \quad=\text { Konstanta } \\
& \mathrm{b} 1, \mathrm{~b} 2, \mathrm{~b} 3=\text { Koefisien Regresi } \\
& \mathrm{X} 1 \quad=\text { Kepemimpinan } \\
& \mathrm{X} 2 \quad=\text { Lingkungan Kerja } \\
& \mathrm{X} 3 \quad=\text { Kemampuan Kerja } \\
& \mathrm{e} \quad \quad=\text { error (variabel bebas lain diluar model regresi) }
\end{aligned}
$$

2. Koefisien Determinasi

Untuk mengetahui besar kecilnya sumbangan $\mathrm{X}$ terhadap sumbangan $\mathrm{Y}$ dapat di tentukan dengan rumus koefisien determinasi berikut :

$\mathrm{KD}=\mathrm{r}^{2} \times 100 \%$

Keterangan :

$\mathrm{KD}=$ Koefisien Determinasi

$r=$ Koefisien Korelasi

1) Uji Hipotesis

a) Uji T

Uji t adalah bagian uji statistik yang merupakan uji koefisien korelasi parsial yang digunakan untuk membuktikan pengaruh variabel independen terhadap variabel dependen, dimana salah satu variabel independennya tetap dikendalikan. (Sugiyono, 2008) merumuskan uji t statistik sebagai berikut:

$$
\mathrm{t}=(\mathrm{r} \sqrt{ }(\mathrm{n}-2)) / \sqrt{ }\left(1-\mathrm{r}^{2}\right) \text {. }
$$


Keterangan:

$\mathrm{t}=$ =Nilai Signifikan

$\mathrm{r}^{2} \quad=$ Koefisien Korelasi Pearson Product Moment

$\mathrm{n} \quad=$ Jumlah Sampel

Dengan kriteria pengambilan keputusan sebagi berikut :

【t】_(hitung ) > $\ \mathrm{t} \rrbracket$ tabel Maka pengambilan hipotesa nol ditolak dan hipotesa alternative diterima artinya ada pengaruh variabel bebas terhadap variabel terikat

『t \_(hitung ) < 『t \_tabel Maka hipotesa nol diterima dan hipotesa alternative ditolak artinya tidak ada pengaruh variabel bebas terhadap variabel terikat Penulis mengajukan hipotesis, dengan tingkat toleransi kesalahan sebesar 5\%.

1. Uji F

Untuk mengetahui signifikansi korelasi ganda dicari dulu 『F \hitung kemudian dibandingkan dengan $\llbracket \mathrm{F} \rrbracket$ tebel Rumus :

[F $\rrbracket$ hitung $=\mathrm{R}^{\wedge} 2 /\left(\left(1-\mathrm{R}^{\wedge} 2\right)\right.$.

Dimana:

$\mathrm{R}=$ Nilai Koefisien Korelasi Ganda

$\mathrm{K}=$ Jumlah Variabel

$\mathrm{N}=$ Jumlah Sampel

[F 』_hitung= nilai f yang

dihitungKriteria pengujian

signifikasi :

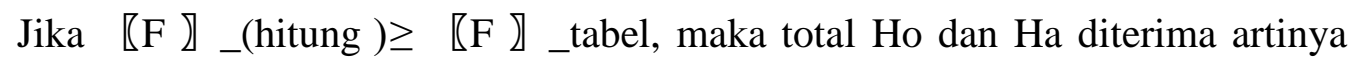
ada pengaruh yang signifikan antara Kepemimpinan, Lingkungan Kerja dan KemampuanKerja terhadap Prestasi Kerja

Jika 『F \_(hitung $) \leq \llbracket F \rrbracket$ tabel, maka total Ho diterima dan Ha ditolak artinyatidak ada pengaruhnya yang signifikan antara Kepemimpinan, Lingkungan Kerja danKemampuan Kerja terhadap Prestasi Kerja.

\section{Hasil dan Pembahasan}

\section{A. Analisis Data dan Pembahasan}

\section{Analisis Data}

a) Regresi linear berganda

Untuk membuktikan Hipotesis penelitian yang diajukan dalam penelitian ini digunakan metode regresi linear berganda dengan menggunakan SPSS ver. 23 dengan hasil analisis sebagai berikut

\section{Tabel 1}

Hasil Analisis Regresi Linear Berganda

\begin{tabular}{|c|c|c|c|c|c|c|}
\hline \multirow{2}{*}{\multicolumn{2}{|c|}{ Model }} & \multicolumn{2}{|c|}{$\begin{array}{l}\text { Unstandardi } \\
\text { zed } \\
\text { Coefficients }\end{array}$} & \multirow{3}{*}{\begin{tabular}{l} 
Standardi \\
zed \\
Coefficien \\
ts \\
\multicolumn{1}{|c}{ Beta }
\end{tabular}} & \multirow[t]{2}{*}{$\mathbf{T}$} & \multirow[t]{2}{*}{ Sig. } \\
\hline & & B & $\begin{array}{l}\text { Std. } \\
\text { Error }\end{array}$ & & & \\
\hline 1 & (Constant) & 25.168 & 30.624 & & .822 & .419 \\
\hline
\end{tabular}




\begin{tabular}{|l|l|c|c|c|c|c|}
\hline & Kepemimpinan & .229 & .109 & .358 & 2.101 & .045 \\
\hline $\begin{array}{l}\text { Lingkungan } \\
\text { Kerja }\end{array}$ & .630 & .247 & .434 & 2.549 & .017 \\
\hline Kemampuan Kerja & -.379 & .424 & -.150 & -.893 & .380 \\
\hline
\end{tabular}

Berdasarkan tabel 4.9 diatas diperoleh persamaan regresi berganda sebagai berikut : $\mathrm{Y}=$ $25.168+0,229 \times 1+0,630 \times 2+(-0,379) \times 3$.

Dengan penjelasan dari persamaan diatas adalah :

1. Nilai $\mathrm{a}=25.168$ Artinya jika variabel kepemimpinan, lingkungan kerja dan kemampuan kerja dianggap nol (0) maka prestasi kerja peagawai Badan Kesbangpol Kabupaten Kerinci menurun sebesar 25.168.

2. Nilai $\mathrm{b} 1=0,229$ Artinya tanda positif mengartikan bahwa pengaruh dari kepemimpinan adalah positif, semaki baik kepemimpinan maka akan cenderung terjadi peningkatan dari prestasi kerja pegawai Badan Kesbangpol Kabupaten Kerinci.

3. Nilai $\mathrm{b} 2=0,630$, Artinya tanda positif mengartikan bahwa pengaruh dari lingkungan kerja adalah positif, semaki baik lingkungan kerja maka akan cenderung terjadi peningkatan dari prestasi kerja pegawai Badan Kesbangpol Kabupaten Kerinci

Nilai b3 $=-0,379$ Artinya tanda negatif mengartikan bahwa pengaruh dari kemampuan kerja adalah terhadap prestasi kerja pegawai Badan Kesbangpol kabupaten Kerinci adalah negatif.

\section{b) Koefisien Determinasi}

Untuk mengetahui seberapa besar pengaruh kepemimpinan, lingkungan kerja dan kemampuan kerja terhadap prestasi kerja Pegawai Badan Kesbangpol Kabupaten Kerinci secara simultan maka dapat dijelaskan pada tabel dibawah ini :

Tabel 2Hasil Uji Koefisien Determinasi

\begin{tabular}{|c|c|c|c|c|c|c|c|c|c|}
\hline \multirow[b]{2}{*}{ Model } & \multirow[b]{2}{*}{$\mathrm{R}$} & \multirow[b]{2}{*}{$\begin{array}{c}\mathrm{R} \\
\text { Square }\end{array}$} & \multirow[b]{2}{*}{$\begin{array}{l}\text { Adjusted } \\
\text { R Square }\end{array}$} & \multirow[b]{2}{*}{$\begin{array}{l}\text { Std. Error } \\
\text { of the } \\
\text { Estimate }\end{array}$} & \multicolumn{5}{|c|}{ Change Statistics } \\
\hline & & & & & $\begin{array}{l}\text { R Square } \\
\text { Change }\end{array}$ & $\begin{array}{c}\text { F } \\
\text { Chang } \\
\text { e }\end{array}$ & df1 & df2 & $\begin{array}{c}\text { Sig. F } \\
\text { Chang } \\
\mathrm{e}\end{array}$ \\
\hline 1 & $.526^{\mathrm{a}}$ & .277 & .193 & 3.845 & .277 & 3.319 & 3 & 26 & .035 \\
\hline
\end{tabular}

Dari perhitungan tabel 4.10 tersebut diperoleh nilai $R$ squere (determinasi) adalah sebesar 0,277 (adalah pengkuadratan dari koefisien korelasi 0,526 (a) Rsquere dapat disebut Koefisien Determinasi yang dalam hal ini $27,7 \%$ besarnya pengaruh variabel kepemimpinan, lingkungan kerja dan kemampuan kerja terhadap prestasi kerja Badan Kesbangpol Kabupaten Kerinci, sedangkan sisanya (100\% - 27,7\%) yaitu $72,3 \%$ dijelaskan oleh faktor-faktor lain yang tidak diteliti dalam penelitian ini.

\section{c) Pengujian Hipotesis}

\section{a. Pengujian Secara Parsial (uji-t)}

Untuk menguji signifikan pengaruh kepemimpinan, lingkungan kerja dan 
kemampuan kerja terhadap prestasi kerja Pegawai Badan Kesbangpol Kabupaten Kerinci secara parsial menggunakan uji t. Dengan tingkat signifikan untuk uji 2 arah $5 \%(0,5)$, dan jumlah responden 30 orang, maka didapat t tabel adalah $=\mathrm{df}=$ $\mathrm{n}-\mathrm{k}$ sehingga $\mathrm{df}=30-4=26$ diperoleh $\mathrm{t}$ tabel $=2,05553$ sedangkan untuk $\mathrm{t}$ tabel dapat dijelaskan pada tabel dibawah ini :

Tabel 3

Hasil Uji Parsial dengan t-test

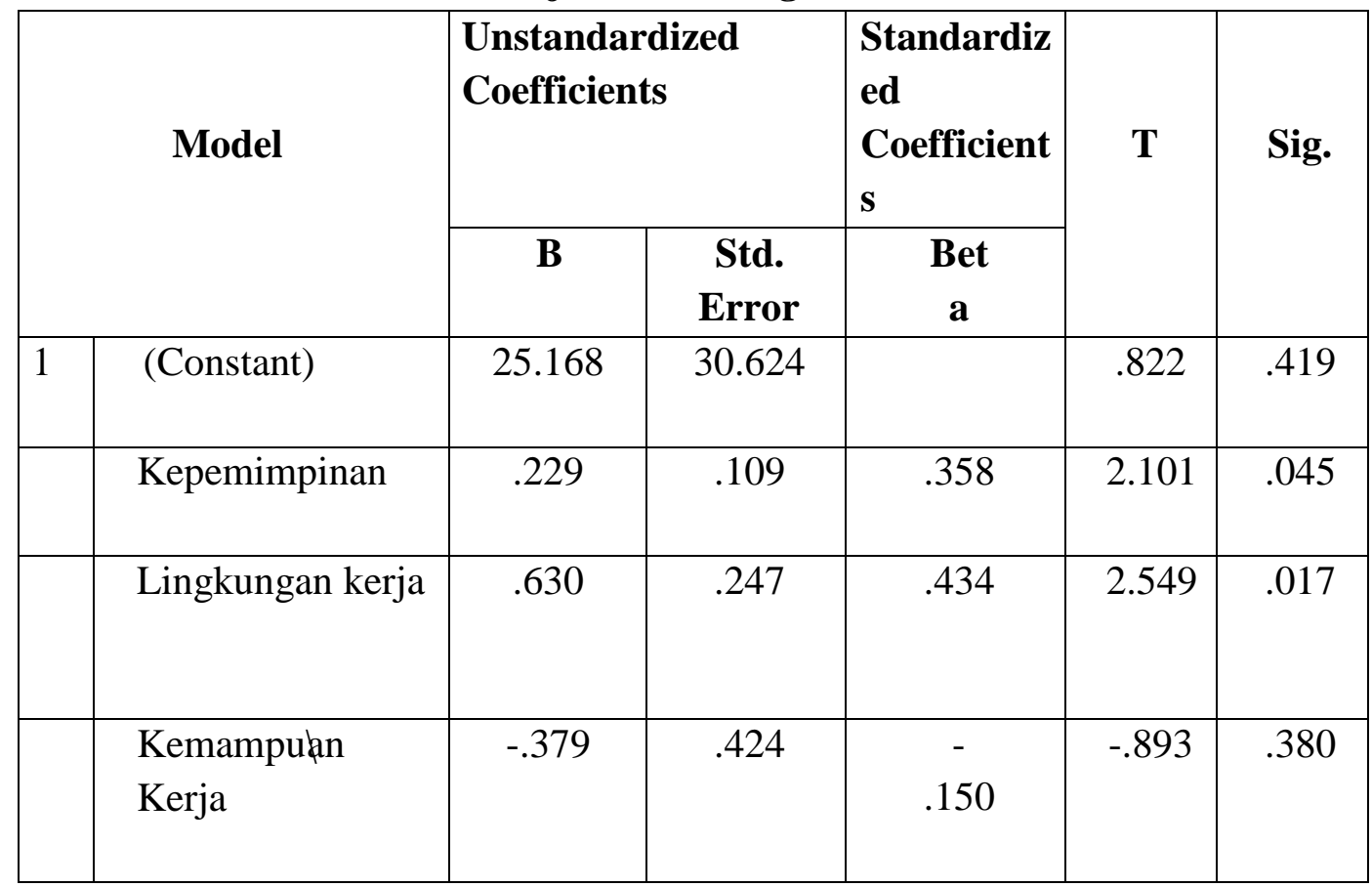

Hasil analisis regresi yang diringkas seperti pada tabel 3 dapat diinterprestasikan sebagai berikut :

a. Kepemimpinan berpengaruh signifikan terhadap prestasi kerja pegawai Badan Kesbangpol Kabupaten Kerinci, ini dibuktikan t hitung > t tabel $(2,101>2,05553)$ serta dengan nilai signifikansi $=0,045<0,5$ maka Ho ditolak dan Ha diterima, artinya terdapat pengaruh yang signifikan antara kepemimpinan terhadap prestasi kerja Pegawai Badan Kesbangpol Kabupaten Kerinci.

b. Lingkungan kerja berpengaruh signifikan terhadap prestasi kerja pegawai Badan Kesbangpol Kabupaten Kerinci, ini dibuktikan t hitung > t tabel $(2,549>2,05553)$ serta dengan nilai signifikansi $=0,017<0,5$ maka Ho ditolak dan Ha diterima, artinya terdapat pengaruh yang signifikan antara lingkungan kerja terhadap prestasi kerja Pegawai Badan Kesbangpol Kabupaten Kerinci.

c. Kemampuan kerja berpengaruh negative terhadap prestasi kerja Pegawai Badan Kesbangpol Kabupaten Kerinci, hal ini dibuktikan dengan $t$ hitung $<t$ tabel $(-0,893$ $<2,05553$ ) maka Ho diterima dan Ha ditolak, artinya tidak terdapat pengaruh yang signifikan antara kemampuan kerja dan prestasi kerja pegawai Badan Kesbangpol Kabupaten Kerinci.

\section{Pengujian Hipotesis Secara Simultan (uji-f)}

Untuk menguji signifikansi pengaruh kepemimpinan, lingkungan kerja dan 
kemampuan kerja terhadap maka didapat $\mathrm{r}$ tabel df $1=\mathrm{k}-\mathrm{f}(4-1=3)$ dan df $2=\mathrm{n}-\mathrm{k}(30$ $-3=37$ ) dimana $\mathrm{k}$ adalah jumlah variabel (bebas + terikat) dan $\mathrm{n}$ adalah jumlah sampel, Sehingga didapat $\mathrm{f}$ tabel 2,96 bisa dilihat pada tabel dibawah ini

Tabel 4

Hasil Uji Simultan dengan F-test

\begin{tabular}{|l|l|l|l|l|l|l|}
\hline \multicolumn{2}{|l|}{ Model } & $\begin{array}{l}\text { Sum of } \\
\text { Squares }\end{array}$ & Df & $\begin{array}{l}\text { Mean } \\
\text { Square }\end{array}$ & F & \multirow{2}{*}{ Sig. } \\
\hline 1 & Regression & 147.157 & 3 & 49.052 & 3.319 & \multirow{2}{*}{$.035^{\mathrm{b}}$} \\
\hline & Residual & 384.309 & 26 & 14.781 & & \\
\hline & Total & 531.467 & 29 & & & \\
\hline
\end{tabular}

Berdasarkan tabel 4 dari uji ANOVA atau F-test didapat $\mathrm{F}$ hitung 3,319 dimana $\mathrm{F}$ hitung .> F tabel $(3,319>2,96)$ serta dengan nilai signifikansi $0,035<0,5$ maka Ho ditolak dan Ha diterima artinya kepemimpinan, lingkungan kerja dan kemampuan kerja berpengaruh signifikan terhadap .

\section{Kesimpulan}

Kerja pegawai Badan Kesatuan Bangsa dan Politik Kabupaten Kerinci tidak baik hal ini dapat dilihat dari rata- rata Total Capaian Responden (TCR) sebesar 56,70\%. Sedangkan kepemimpinan berada pada kondisi baik dengan Total Capaian Responden (TCR) sebesar 82,83\%. lingkungan kerja berada pada kondisi sangat baik dengan Total Capaian Responden (TCR) sebesar 91,96\% dan kemampuan kerja berada pada kondisi sangat baik dengan Total Capaian Responden (TCR) sebesar 95,93\%.

Kepemimpinan berpengaruh positif terhadap , ini dibuktikan $\mathrm{t}$ hitung $>\mathrm{t}$ tabel $(2,101>$ 2,05553).

Lingkungan kerja berpengaruh positif terhadap , ini dibuktikan $\mathrm{t}$ hitung $>\mathrm{t}$ tabel $(2,549$ $>2,05553$ ).

Kemampuan kerja berpengaruh negative terhadap , hal ini dibuktikan dengan $\mathrm{t}$ hitung $<$ t tabel $(-0,893<2,05553)$.

Nilai b1 = 0,229 Artinya tanda positif mengartikan bahwa pengaruh dari kepemimpinan adalah positif, semaki baik kepemimpinan maka akan cenderung terjadi peningkatan dari prestasi kerja pegawai Badan Kesbangpol Kabupaten Kerinci.

Nilai b2 $=0,630$, Artinya tanda positif mengartikan bahwa pengaruh dari lingkungan kerja adalah positif, semaki baik lingkungan kerja maka akan cenderung terjadi peningkatan dari prestasi kerja pegawai Badan Kesbangpol Kabupaten Kerinci

Nilai b3 = - 0,379 Artinya tanda negatif mengartikan bahwa pengaruh dari kemampuan kerja adalah terhadap prestasi kerja pegawai Badan Kesbangpol kabupaten Kerinci adalah negatif. 
Kepemimpinan, lingkungan kerja dan kemampuan kerja berpengaruh terhadap prestasi kerja Badan Kesbangpol Kabupaten Kerinci sebesar 27,7\% sedangkan sisanya (100\% - 27,7\%) yaitu $72,3 \%$ dijelaskan oleh faktor- faktor lain yang tidak diteliti dalam penelitian ini. 


\section{Bibliografi}

Afifi, M. D., Al Musadieq, M., \& Nurtjahjono, G. E. N. E. N. (2015). Pengaruh Kemampuan Kerja Dan Motivasi Kerja Terhadap Prestasi Kerja (Studi Pada Karyawan Pr. Sejahtera Abadi Malang). Jurnal Administrasi Bisnis, 29(1), 19-25.

Nitisemito. (2004). Manajemen Personalia. Ghalia Indonesia.

Rivai, V., \& Mulyadi, D. (2003). Kepemimpinan dan perilaku organisasi. Jakarta: Raja Grafindo Persada.

Simanjuntak, Payaman, J. (2011). Pengantar Ekonomi Sumber Daya Manusia. Penerbit FE UI.

Sugiono, A. (2008). Panduan Praktis Dasar Anlisa Laporan Keuangan. Gramedia Widiasarana.

Sugiyono. (2008). Metode Penelitian Kunatitatif Kualitatif dan R\&D. Bandung Alfabeta.

Sutrisno, A., Nguyen, N. T., \& Tangen, D. (2014). Incorporating translation in qualitative studies: Two case studies in education. International Journal of Qualitative Studies in Education, 27(10), 1337-1353.

Winardi, J. (2004). Motivasi dan Pemotivasian Manajemen. Jakarta: PT. Raja Grafindo Persada. 